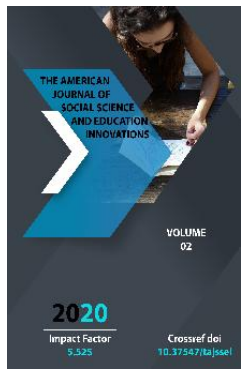

\title{
Computerization Technology Of Music Education
}

\author{
Abdumannon Makhammatov \\ Senior Lecturer, Jizzakh State Pedagogical Institute, Uzbekistan
}

Journal Website:

http://usajournalshub.c

om/index,php/tajssei

Copyright: Original

content from this work

may be used under the

terms of the creative

commons attributes

4.0 licence.

\section{ABSTRACT}

The essence of the formation of the issues of accelerated introduction of computerization of education in the lessons of "Music Culture" in the school in the process of educating students.

\section{KEYWORDS}

Music culture, education, computer, informatization, lifelong learning, style, means, activity.

\section{INTRODUCTION}

Along with updating, improving and improving the quality of education, teachers and trainers need to improve their skills, keep pace with the development of science, especially in the field of information technology, which can be used effectively in all areas, interactive methods, One of the most important tasks today is to be able to communicate freely with a computer and apply it in their work to ensure the effectiveness of the lesson.

THE MAIN FINDINGS AND RESULTS
The introduction of interactive methods, innovative pedagogical technologies and their skillful use play an important role in improving the effectiveness of the teaching process. After all, in traditional education, students are taught to acquire only ready-made knowledge, while in accordance with the criteria of developmental education, students are able to study, analyze and draw conclusions on their own. plays an important role in the direction of Therefore, the system of education organized in pedagogical higher education institutions helps to develop the 
skills of future teachers who can use interactive methods, advanced pedagogical technologies in their work, as well as their creative and free application in practice. It is necessary to pay attention.

According to the theory of such systems, human activity is the leading component, and the machine is a means of its effective implementation. There are many forms and forms of human activity, the genetic basis of which is the type of labor activity, such as play, study, research. The organization of students' learning activities with the help of computers allows them to be effective. In addition, the computerization of education is a system of continuous education, as well as a continuous basis for informing the public.

One of the most important directions in informing the public is the informatization of the system of continuing education. Informatization of the system of continuing education is an important condition for the successful implementation of the process of informatization of society. This process includes the use of new information technologies for the effective implementation of education, the use of its methods and tools, the acceleration of all stages of the educational process, improving its quality and efficiency, preparing young people to live in an informed society.

The need for computerization of the educational process arose from the task of educating students to become full-fledged citizens of society. In today's society, where all spheres of human activity are computerized, it is important to teach the younger generation to communicate freely with computers.

The extensive use of computers by young people serves to accelerate the development of science and technology in society and, on this basis, to achieve socio-economic development.

Computerization of education makes a huge contribution to the development of human intelligence. This is because in the process of computer-assisted learning, induction and deduction, generalization and concretization, analysis and synthesis, classification and systematization, abstraction and simulation are naturally included. These, in turn, contribute to the growth of logical reasoning.

The experience of computer-based education shows that the formal use of computers in the system of continuing education does not give the expected results. To be effective in this process, it is necessary to develop the prospects of didactic and psychological concepts, the content of educational disciplines and the logic of their development, the characteristics of teaching methods, the theory and technology of the educational institution. "Computerization of education is not the goal.

It is necessary to develop a theory and technology for the design of PDVs to the extent that it can affect the components of the didactic education system, including all the goals, principles, content, methodology, form and description of the process of knowledge acquisition.

Education is an organizational process formed on the basis of the interaction of teacher and student. At the heart of it is the interaction of teaching and learning activities. The essence of the educational process can be understood through a comprehensive analysis of teaching and learning activities. In computer education, too, the separation of teaching and learning activities, their proper organization, the extensive use of computer capabilities in the implementation of activities are important.

All the teachers who are educating the youth and equipping them with social experience and spiritual wealth are engaged in teaching activities. In computer training, such activity is the responsibility of the computer.

In the process of computer-based learning, education is organized, managed, controlled 
according to the relationship between the student and the computer.

Organization of computer-based education the establishment of computer-based communication between students and educational materials.

The organization of communication between the student and the educational material, the stimulation of their activities is modeled on the basis of appropriate means.

Management of computer-based education is understood as the achievement of a student's transition from one type of activity to another on the basis of computer programs, and on this basis to raise the level of mastering the material from the lowest to the highest level. Computer programs analyze the responses of students to the requirements of education management; provide management of computer work according to the instructions given by the program.

Computer-assisted learning is the study of the inverse relationship between computerassisted learning and learning. According to the feedback, the results of the educational process are analyzed; shortcomings in the activities of students are identified and filled.

The educational activity of a computer is very complex in structure and includes didactic tasks, educational tasks, teaching materials, teaching methods, which are integrated into computer programs. Didactic task - the work that the computer does in the learning process. During the training, the computer performed the following didactic tasks: prepares students to study the material; strengthens, systematizes, identifies and fills in knowledge, skills, and abilities.

The didactic tasks of the computer are ideally projected in the mind of the stylist-teacher before the creation of the computer program.

In designing the educational process, the teacher analyzes the new teaching material from the essence of teaching, analyzes the teaching material, assignments, teaching methods, tools and combines them with the capabilities of the computer. selects the appropriate ones from them.

The student's model covers the situation in which the learner is exposed to various questions, its specific characteristics and the history of teaching in this system.

The teacher's model compares the actions of the expert with the solution of the problem with the studied action and defines the essence of consistency in education.

The interfaces used provide a variety of ways to convey the learning material to the student, as well as provide a basis for the emergence of student questions in the system. Such directions should be taken into account in computer training.

The idea of forming students into full-fledged, mature people will be the basis of computer education. In this sense, the main direction is to increase the creative activity of students in the methodology of designing new pedagogical and information technologies, computer music education on their basis, the introduction of innovations in the field of methodology in the process of music education.

Repertoire selection is a very responsible process. After all, this is an important factor in determining the quality of development of musical culture in students. In the process of learning the song, students develop musical memory, listening skills, vocal choir skills, students understand the content of the work, the artistic image.

Therefore, in choosing the repertoire, we consider it expedient to define it based on the following principles;

- From an educational point of view, how can this work affect the formation of student psychology; 
- From a pedagogical point of view, how can the song be used in the development of some principles of music?

\section{CONCLUSION}

In the selection of melodies, great attention was paid to their emotional sensitivity, artistic value, ease of assimilation; Students were also introduced to musical concepts, music marsh, playfulness, image features, and means of musical expression. B.M. Teplov said: "It is impossible to create, play, and draw as an exercise in one activity. Only a part of a child's artistic activity is focused on creating a product, which is necessary for someone to be able to make an impact ... Instead of the general development of the child, only one of his skills will develop. "1 (7-13). In the same way, each product created by children was analyzed in the following separate ways suggested by teachers:

- Creates the need for knowledge in students;

- activates students' need for knowledge;

- Increases students' interest in studying music culture;

- allows students to form and develop executive skills;

- There is an opportunity to individualize the teacher.

\section{REFERENCES}

1. Karimov I.A. (2008) High spirituality is an invincible force. - Tashkent: "Ma'naviyat". - p. 176.

2. Mirziyoev Sh.M. (2016) Together we will build a free and prosperous, democratic state of Uzbekistan. - Tashkent. Uzbekistan.

3. Mirziyoev Sh. M. (2017) We will build our great future together with our brave and noble people. - Tashkent. Uzbekistan.

4. Mirziyoev Sh. M. (2017) We will resolutely continue our path of national development and take it to a new level. Tashkent. Uzbekistan.

5. Baubekova G.D., Khalikova G.T. (2001) Innovative technologies for optimizing the educational process. - In the book: Education: opt, problem, perspective. Tutorial. - Tashkent. "Yangi ASR AVLODI". - pp. 67-99.

6. Resolution of the Cabinet of Ministers of the Republic of Uzbekistan "On measures to implement the state national program for the development of school education in 2004-2009" Journal of Educational Development, 2004. No. 5.

7. Order No. 149 of the Ministry of Education and Science of the Republic of Uzbekistan "On further improvement of the system of retraining and advanced training of teachers" GG "Ma'rifat" newspaper. - Tashkent. June, 2006.

8. Hoshimov K., Achil S. (1999) Anthology of Uzbek pedagogy. - Tashkent. "Teacher”.

9. Rubob melodies. Collection. Tashkent. Teacher. - p. 128.

\section{The USA Journals Volume 02 Issue 10-2020}

